\title{
KUALITAS AUDIT MELALUI ANALISIS FAKTOR- FAKTOR INDEPENDENSI DAN PROFESIONALISME AUDIT INTERNAL
}

\author{
Ari Bramasto $^{1}$, Sri Dewi Anggadini2 ${ }^{*}$, Asri Syahriani ${ }^{3}$ \\ ${ }^{1}$ Universitas Langlangbuana, ari.bramasto2019@gmail.com \\ ${ }^{2}$ Universitas Komputer Indonesia, sri.dewi@email.unikom.ac.id (Corresponding Author) \\ ${ }^{3}$ Universitas Langlangbuana, asrisyahriani15@gmail.com
}

\begin{abstract}
ABSTRAK
Kualitas audit adalah ketepatan informasi yang dilaporkan auditor sesuai dengan standar audit yang digunakan auditor termasuk informasi pelanggaran akuntansi dalam laporan keuangan perusahaan, untuk itu peran auditor internal penting bagi keberlanjutan perusahaan, dimana perannya adalah memberikan pengawasan serta penilaian terus menerus, maka kualitas audit yang dihasilkan bergantung dari Independensi dan profesionalisme auditor itu sendiri. Penelitian ini bertujuan untuk mengetahui seberapa besar pengaruh Independensi Audit Internal terhadap kualitas audit dan seberapa besar pengaruh profesionalisme auditor internal terhadap kualitas audit pada PT Foximas Mandiri Bandung. Metode yang digunakan dalam penelitian ini adalah metode deskriptif dan verifikatif. Populasi dalam penelitian ini adalah pegawai PT Foximas Mandiri Bandung. Pengambilan sempel dilakukan dengan Teknik Sensus, dengan sampel 26 responden. Jenis data yang digunakan dalam penelitian ini adalah data primer. Teknik pengumpulan data menggunakan permodelan uji statistik dengan menggunakan program SPSS V.22. Hasil penelitian ini menunjukan bahwa : 1) Independensi Audit Internal berpengaruh terhadap kualitas audit, auditor internal bebas dari tekanan atau intervensi manajerial dan menghindari penggunaan bahasa yang tidak jelas dalam laporan audit menjadi faktor dengan gap terendah yaitu sebesar 9,23\% 2) Profesionalisme Audit Internal berpengaruh terhadap kualitas audit, keyakinan terhadap peraturan perofesi menjadi faktor dengan gap terendah yaitu sebesar $1,54 \%$
\end{abstract}

Kata Kunci : Independensi, Profesionalisme Auditor Internal, Kualitas Audit

\section{ABSTRACT}

Audit quality is the accuracy of information reported by the auditor in accordance with the auditing standards used by the auditor including information on accounting violations in the company's financial reports, for that the role of the internal auditor is important for the sustainability of the company, where its role is to provide continuous supervision and assessment, the resulting audit quality depends of the independence and professionalism of the auditors themselves. This study aims to determine how much influence the independence of Internal Auditon audit quality and how much influence the professionalism of internal auditors on audit quality at PT Foximas Mandiri Bandung.

The method used in this research is descriptive and verification methods. The population in this study were employees of PT Foximas Mandiri Bandung. Sampling was done using the Census Technique, with a sample of 26 respondents. The type of data used in this study is primary data. The data collection technique used statistical test modeling using the SPSS V.22 program.

The results of this study indicate that: 1) The independence of the Internal Audit has an effect on audit quality, the internal auditors are free from pressure or managerial intervention and avoiding the use of unclear language in the audit report being the factor with the lowest gap, namely 9.23\% 2) Professionalism of Internal Audit influence on audit quality, confidence in perophysical regulations is the factor with the lowest gap, namely $1.54 \%$.

Keywords : Independence, Profesionalism, Internal Audit, Audit Quality.

Naskah diterima : 13-03-2021, Naskah dipublikasikan : 30-04-2021 


\section{PENDAHULUAN}

Dalam perekonomian modern, antara pemilik dan pengelola (manajemen) pada banyak perusahaan dilakukan pemisahan. Besarnya kepercayaan dari pengguna laporan keuangan yang diberikan kepada auditor, mengharuskan auditor memperhatikan kualitas auditnya. Efisiensi dan efektivitas suatu perusahaan dari kegiatan usahanya agar meningkat departemen audit internal dibutukan keberadaannya (Ariany, 2017). Dalam struktur organisasi perusahaan adanya auditor internal menjadi bagian yang integral, berperan melakukan pengawasan dan penilaian secara berkesinambungan. Auditor internal mampu independen bila mereka dapat melakukan pekerjaanya dengan bebas dan obyektif. Adanya independensi pada auditor internal sehingga tidak bias dan tidak memihak di dalam membuat keputusan dan menjalankan tugasnya. Independensi ini akan dapat tercapai pada status organisasi audit internal dan obyektifitas dalam mengaudit ( Hery, 2016). Auditor berprofesi menjalankan tugas dalam memberikan jaminan pada manajemen dalam membuat laporan keuangan untuk stakeholder telah sesuai dengan standar akuntansi keuangan di Indonesia.Konsep Kualitas audit memperlihatkan auditor mampu mengerjakan tugas profesionalnya sesuai etika profesi, independensi dan kompetensi (Junaidi dan Nurdiono, 2016).

Kualitas Audit pada PT.KAI sebagai contoh kasus fenomena. Kasus Perbedaan pandangan pada awalnya antara manajemen dan komisaris yang merangkap menjadi Ketua Komite Audit, dimana komisaris tersebut menolak untuk menyetujui serta menandatangani laporan keuangan hasil audit auditor eksternal dan laporan keuangan yang telah di audit di minta audit ulang. Hal ini karena PT KAI memiliki stasiun berjumlah ratusan, depo dan gudang ada beberapa, laporan keuangan dimiliki terpisah pasti seluruhnya, kondisi demikian memiliki potensi permasalahan dan pendapat yang berbeda nantinya. Belum lagi kenyataan bahwa Penggunaan sistem computer masih terbatas pada proses akuntansinya, Sementara dalam penyusunan laporan keuangan pada PT KAI sistem akuntansinya relatif modern. Penyebab masalah dari sejumlah transaksi yakni diantaranya auditor internal tidak aktif proses penunjukan auditnya, bahkan hanya auditor eksternal berperan aktif. Hal lainnya, komite audit tidak memiliki peran pada auditor yang ditunjuk maka berakibat proses auditnya tidak dilibatkan (Ramdani, 2017)

Fenomena lain yaitu Kementrian Keuangan Republik Indonesia Sri Mulyani menyatakan bahwa auditor internal mempertahankan profesionalismenya selain memperhatikan sistem dalam negeri namun juga yang dianut oleh sistem global. Menteri keuangan di Indonesia merupakan pembina auditor internal seluruh indonesi, maka Inspektorat Jendral bila mengabaikan pembinaan secara baik dapat berpengaruh terhadap kualitas auditor binaannya. Inspektorat Jendral mempersiapkan metedologi meliputi penyusunan risiko, penerapan perencanaan pengawasan tahunan berbasis risiko dan kontrol matriks klien pengawasan, pengujian pengendalian dan subtantif, penggunaan metode data analitik berikut penyeragaman penyusunan simpulan hasil (Sri Mulyani, 2018).

\section{KAJIAN LITERATUR Independensi}

Zamzami (2018) menyatakan bahwa, "Independensi adalah kebebasan dari kondisi yang mengancam kemampuan aktivitas audit internal untuk melaksanakan tanggung jawab audit internal dengan cara tidak memihak. Untuk mencapai tingkat independensi membutuhkan efektivitas utuk melakukan tanggung jawab pada aktivitas audit internal". Nasution (2019) memandang bahwa : Independensi adalah sikap tidak memihak kepada kepentingan siapapun dalam melakukan pemeriksaan laporan keuangan yang dibuat oleh pihak manajemen. Auditor mempunyai kewajiban untuk bersikap jujur tidak saja kepada pihak manajemen, tetapi juga terhadap pihak ketiga sebagai pemakai laporan keuangan, seperti kreditor, pemilik maupun calon pemilik.

\section{Profesionalisme}

Sebagaimana dikemukakan oleh Sya'bani (2018) bahwa : Profesionalisme dapat diartikan sebagai suatu kemampuan dan keterampilan seseorang dalam melakukan pekerjaan menurut bidang dan tingkatnya masing-masing Profesionalisme menyangkut kecocokan antara kemampuan yang dimiliki oleh birokrasi 


\section{JURNAL AKUNTANSI, Vol. 10, No. 1, April (2021)}

dengan kebutuhan tugas merupakan syarat terbentuknya aparatur yang professional. Menurut Arifin dalam Rusman (2017:152), "Profesionalisme adalah keahlian tertentu berdasarkan suatu sudut pandangan tertentu pula pada pekerjaan tertentu, yang didapatkan dengan pendidikan tersendiri atau pembinaan tersendiri pula". Kemudian Ardianingsih (2018:31) berpendapat bahwa, "Profesionalisme adalah orang yang berprofesi dan hidup dari pekerjaan tersebut serta memiliki suatu keahlian yang tinggi".

\section{Audit Internal}

Zamzami (2018) memandang bahwa : Audit internal adalah kegiatan independen dan objektif dengan memberikan jasa asuransi dan konsultasi, perancangan penambahan nilai dan operasi organisasi ditingkatkan. Audit iternal menunjang organisasi meraih tujuannya melakukan pendekatan sistematis dan teratur pada evaluasi dan kemajuan pengendalian, manajemen risiko yang efektif, dan pengelolaan proses itu sendiri. Sementara Hery (2017) berpendapat bahwa, "auditor internal merupakan auditor menjalani tugasnya pada manajemen suatu perusahaann dalam memperoleh status sebagai pegawai perusahaan tersebut".

\section{Kualitas Audit}

Yadiati dan Mubarok (2017) mengemukakan bahwa, "Kualitas Audit adalah akurasi informasi laporan auditor berdasarkan standar audit yang dipakai auditor termasuk informasi adanya akuntansi yang dilanggar pada laporan keuangan perusahaan ". Sedangkan menurut Junaidi dan Nurdiono (2016), "kualitas audit merupakan Indikasi kesalahan material pada laporan keuangan sebagai Probabilitas dan kekeliruan tersebut akan ditemukan oleh auditor". Chandegani dalam Yadiati dan Mubarok, 2017) menyatakan bahwa, "kualitas audit merupakan deteksi salah material dan kesalahan yang terjadi dapat dilaporkan sebagai kemampuan auditor".

\section{METODE PENELITIAN}

Penelitian ini menggunakan beberapa tipe desain penelitian sebagai berikut :

\section{Penelitian Deskriptif}

Penelitian deskriptif adalah variabel masing-masing dapat diketahui nilainya dalam penilitian, Sifat independen hubungan maupun perbandingan dari satu atau lebih variabelnya diabaikan dengan variabel yang lain. (Sujarweni, 2015)

\section{Penelitian Verifikatif}

Penelitian verifikatif yaitu Sesuatu yang pernah ditulis dibidang tertentu di uji kebenarannya dan rumusan kesimpulan sebelumnya berlaku secara umum agar dapat diterima kebenarannya (Widi, 2018).

\section{Penelitian Kuantitatif}

Penelitian kuantitatif adalah hasil jenis penelitian yang dicapai dengan memanfaatkan beberapa prosedur statistik atau berbagai cara yang berbeda dari pengukuran (Sujawerni, 2015).

Pengumpulan data mengunakan cara menyesuaikan dengan kondisi dan keadaan objek penelitian sebagai berikut :

\section{Wawancara}

Wawancara adalah instrumen yang dipakai supaya tergali data secara lisan dan supaya memperoleh data yang detail dan valid (Sujawerni, 2015).

\section{Observasi}

Observasi merupakan gejala yang muncul dilakukan pengamatan dan pencatatan sistematik objek penelitiannya (Sujawerni, 2015).

\section{Kuesioner}

Kuesioner yakni teknik pemberian pertanyaan atau pernyataan tertulis yang di kumpulkan dari para responden untuk menjawabnya. (Sujawerni, 2015)

Langkah berikutnya bila kuesioner sudah selesai dan terkumpulnya data yakni proses tabulasi dan dialihkan dalam bentuk angka memakai skala Likert. Skala Likert menurut Sugiyono (2017) Ukuran sikap, pendapat dan persepsi seseorang atau sekelompok orang berkenaan dengan fenomena sosial. Menurut 


\section{JURNAL AKUNTANSI, Vol. 10, No. 1, April (2021)}

Sudjana (Fatihudin, 2016) "Populasi amerupakan Terjadinya totalitas nilai, hasil perhitungan, kuantitatif bisa juga kualitatif pada sifat tertentu karakternya berkaitan dengan obyek yang terkumpulnya jelas dan lengkap untuk mengetahui sifat-sifatnya". Popolasi dalam penelitian ini adalah seluruh pegawai di PT. Foximas Mandiri Bandung sebanyak 26 orang. Sampling jenuh atau sensus digunakan dalam penelitian ini karena populasi pada PT. Foximas Mandiri hanya 26 orang, sehingga seluruh Populasi dijadikan sampel.

\section{Metode Pengujian Data}

Rukajat (2018) menyatakan bahwa tingkat pengukuran skala adalah berbentuk ordinal, sehingga kesetaraan data didapatkan lebih lanjut untuk itu skala tersebut diolah dahulu menjadi skala interval memakai Method of Succesive Interval. Menurut Riyanto (2020) : Uji Asumsi Klasik merupakan uji persyaratan pada uji regresi dengan cara etimasi Ordinal Leas Square. Uji asumsi klasik perolehannya memenuhi asumsi maka dihasilkan Best Linear Unbiased Estimation. Sebaliknya, bila uji asumsi tidak terpenuhi kriteria asumsi, menimbulkan model regresi akan menghasilkan bias maknanya dan interprestasi sulit jadinya.

Riyanto (2020) Uji normalitas bertujuan menguji model regresi, variabel pengganggu atau residual memiliki distibusinormal. Terdistribusi normal persyaratan yang harus terpenuhi dari hasil uji normalitas, karena asumsi nilai residual mengikuti distribusi normal untuk uji t dan uji f. Uji Autokorelasi bertujuan menguji metode regreresi linear terdapat korelasi antara kesalahan pengganggu rentang waktu $t$ dengan kesalahan pengganggu rentang waktu sebelumnya $(\mathrm{t}-1)$ Autokorelasi muncul akibat adanya observasi urutan waktu yang berkaitan satu dengan lainnya (Riyanto, 2020). Uji Multikolinieritas adalah korelasi tinggi diantara variabel bebas. (Riyanto, 2020). Menurut Riyanto (2020) Uji heteroskedastisitas bertujuan memastikan terjadi ketidaksamaan variance dari residual satu pengamatan dengan lainnya dari uji model regresinya.

\section{Metode Analisis Data}

Menurut Riyanto (2020) Penggunaan uji regresi linear berganda dengan persyaratan satu variabel terikat dengan variabel bebas yang digunakan jumlahnya lebih dari satu. Analisis korelasi menurut Riyanto (2020) yaitu penentuan dengan metode statistika derajat hubungan linier dua variabel atau lebih. Analisis koefisien determinasi $\left(\mathrm{R}^{2}\right)$ merupakan penjelasan variabel terikat yang diukur berdasarkan kemampuan modelnya. Riyanto (2020) berpendapat bahwa "Uji t merupakan pengujian signifikansi pengaruh masingmasing antara varaibel bebas terhadap variabel terikatnya.

\section{Kerangka Pemikiran}

Penelitian ini memiliki kerangka pemikiran yang dapat digambarkan sebagai berikut :

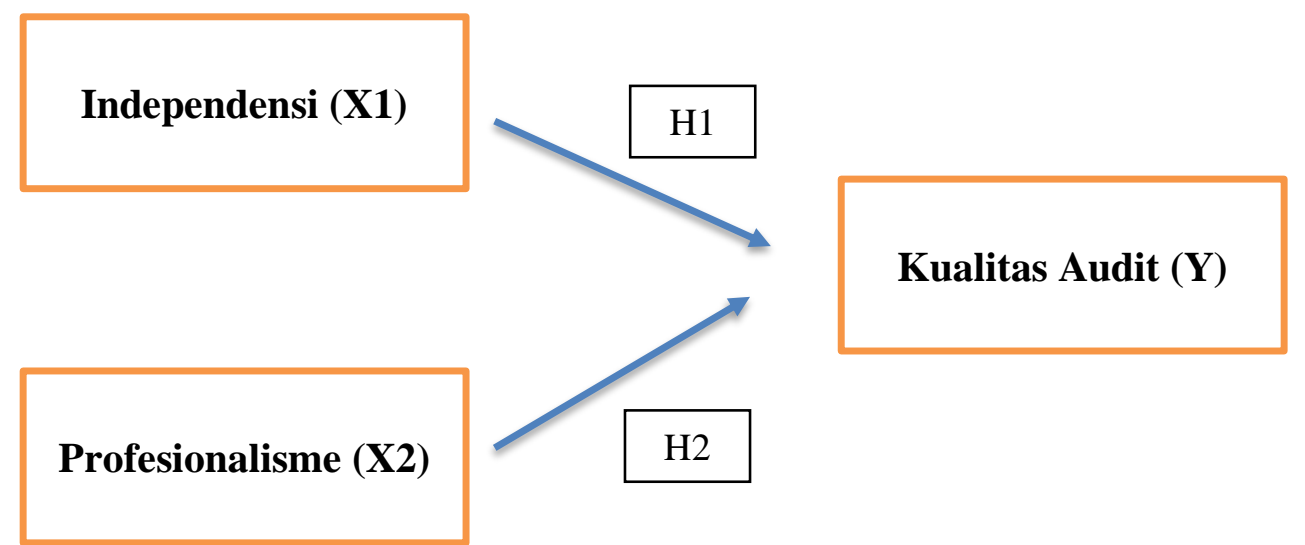

Gambar 1. Kerangka Pemikiran 
Berdasarkan kerangka pemikiran diatas, penulis mencoba merumuskan hipotesis yang merupakan kesimpulan sementara dari penelitian sebagai berikut :

- H1 : Independensi Berpengaruh Terhadap Kualitas Audit.

- H2 : Profesionalisme Berpengaruh Terhadap Kualitas Audit.

\section{HASIL DAN PEMBAHASAN Hasil Penelitian}

Rekapitulasi jawaban responden untuk variabel Independensi pada penelitian ini menghasilkan kategori "Setuju" sebab variabel ini masuk kedalam Interval berkisar "708,2 - 873,4". Diambil dari beberapa responden mengenai pernyataan yang dijawab oleh responden yaitu pada pertanyaan bebas dari tekanan atau intervensi manajerial dalam menentukan, mengeliminasi atau memodifikasi bagian-bagian tertentu dalam audit dan pada pertannyaan menghindari penggunaan kata-kata tidak jelas baik yang disengaja ataupun tidak disengaja dalam membuat laporan dengan total skor 118 dari 869 atau sebesar 13,58\% dan Gap sebesar 9,23\%. Hal ini dapat diketahui bahwa variabel Independensi auditor internal terhadap kualitas audit sudah dalam kondisi cukup baik. Rekapitulasi jawaban responden berkenaan dengan variabel Profesionalisme dalam penelitian ini menghasilkan kategori "Sangat Setuju" karena variabel ini masuk kedalam Interval berkisar "1.420 - 1.690". Diambil dari beberapa pernyataan yang dijawab oleh responden yaitu pada pernyaataan adanya peraturan profesi menjadi motivasi bagi diri sendiri untuk memberikan hasil pekerjaan yang bisa di pertanggung jawabkan dengan perolehan skor total 128 dari 1.485 atau $8.61 \%$ dengan Gap sebesar 1,54 \% . Hal ini dapat diketahui bahwa variabel Profesionalisme audit internal terhadap kualitas audit sudah dalam kondisi baik

Berdasarkan rekapitulasi jawaban responden dalam penelitian ini maka terkait variabel Kualitas Audit menghasilkan kategori " Sangat Setuju" karena variabel ini masuk kedalam Interval berkisar "1.093 - 1.300". Diambil dari pernyataan yang dijawab oleh responden yaitu pada memiliki keahlian dan pelatihan teknis untuk melaksanakan audit dengan perolehan skor total 123 dari 1.113 atau 11,05\%. Berdasarkan hasil uji Kolmogrov Smirnov. Diperoleh uji normalitas dengan nilai signifikansi Asymp. Sig. (2-tailed) sebesar 0,176. Nilai signifikansi ( $p$-value) tersebut lebih besar dari 0,05 sehingga dapat disimpulkan bahwa data sudah memenuhi asumsi normalitas. Uji Autokorelasi diperoleh nilai DW sebesar 1,651. Perabandingan nila DL dan nilai Du pada nilai Durbin- Watson menggunakan $\alpha=0,05$. Variabel bebas (k) $=2$ dan sampel sebanyak $(\mathrm{n})=26$. Berdasarkan Nilai DW maka $(\mathrm{DL})=1.224$ dan $(\mathrm{DU}) 1553$. Hasil DW(1.651) > DL (1.224) sehingga tidak ada autokorelasi positif. nilai VIF sebesar 1,646 dengan Independensi dan Profesionalisme sebagai variabelnya yang membuat nilai VIF $<10,00$ dan nilai tolerance $>0,10$ yakni 0,607, maka tidak ada gejala multikolinieritas hasil modelnya. Pada metode scatter plot tidak ada pola yang jelas, serta titik- titik menyebar di atas dan dibawah angka 0 sumbu $\mathrm{Y}$, maka dapat dipastikan tidak terjadi Heteroskedastisitas.

\section{Analisis Regresi Linier Berganda}

Hasil Penelitian didapat nilai konstanta dari koefisien regresi sehingga dapat dibentuk persamaan regresi linier berganda sebagai berikut :

$$
\mathrm{KA}=13,936+0,395 \mathrm{I}+\mathbf{0 , 2 7 7} \mathrm{PAI}+\mathrm{e}
$$

Keterangan :

$\begin{array}{ll}\text { KA } & : \text { Kualitas Audit } \\ \text { I } & : \text { Independensi } \\ \text { PAI } & : \text { Profesionalisme Auditor Internal } \\ \text { e } & : \text { Faktor-faktor lain } \\ \text { a } & : 13,936, \text { artinya : Jika nilai Independensi dan Profesionalisme } \\ & \text { Auditor Internal 0, maka nilai Kualitas Audit sebesar 13,936 }\end{array}$




\section{Analisis Koefisien Korelasi}

Koefisien Determinasi $\left(R^{2}\right)$ digunakan untuk mengukur kemampuan variabel-variabel independen secara simultan dalam memberikan kontribusi atau pengaruh terhadap variabel dependen. Dengan menggunakan software SPSS v.22 diperoleh output sebagai berikut :

Tabel 1. Hasil Analisis Determinasi

\begin{tabular}{|r|c|r|r|rr|}
\hline \multicolumn{5}{|c|}{$\begin{array}{c}\text { Model } \\
\text { Summary }\end{array}$} \\
\hline $\begin{array}{r}\text { Mode } \\
1\end{array}$ & $\mathrm{R}$ & R Square & Adjusted R Square & $\begin{array}{r}\text { Std. Error of the } \\
\text { Estimate }\end{array}$ \\
\hline 1 & $\begin{array}{r}, 751 \\
\mathrm{a}\end{array}$ &, 564 &, 526 & 1,858 \\
\hline \multicolumn{5}{|c|}{ a. Predictors: (Constant), profesionalisme, independensi } \\
\hline
\end{tabular}

Berdasarkan pada tabel 1 menghasilkan nilai koefisien determinasi sebesar 0,564 berdasarkan $R$ Square. Nilai $R$ Square $=(0,751 \times 0,751)$ setara dikuadratkan maka hasilnya 0,564 sesuai di $R$ Square . Tergambar bahwa Independensi dan Profesionalisme sebagai variabel bebas keduanya memiliki pengaruh terhadap Kualitas audit Internal sebesar 56,4\%, sementara itu sisanya 43,6 \% dipengaruhi faktor lain yang tidak diteliti.

\section{Pengujian Hipotesis}

Nilai thitung untuk Independensi (X1) sebesar 2,453 dengan ttabel 1,710. Dikarenakan nilai thitung lebih besar dari nila ttabel $(2,453>1,710)$ diproleh hasil hipotesisnya yaitu $\mathrm{H}_{\mathrm{O}}$ ditolak dan $\mathrm{H}_{\mathrm{a}}$ diterima, artinya Independensi (X1) berpengaruh signifikan terhadap Kualitas Audit (Y) pada PT. Foximas Mandiri.

Nilai thitung untuk Profesionalisme (X2) sebesar 2,256 dengan ttabel 1,710. Akibat nilai thitung lebih besar dari nila tabel $(2,256>1,710)$ hasil hipotesisnya yaitu $\mathrm{H}_{\mathrm{O}}$ ditolak dan $\mathrm{H}_{\mathrm{a}}$ diterima, artinya Profesionalisme (X2) berpengaruh signifikan terhadap Kualitas Audit (Y) pada PT. Foximas Mandiri.

\section{Pembahasan}

\section{Pengaruh Independensi Terhadap Kualitas Audit}

Berdasarkan hasil penelitian, diperoleh hasil bahwa variabel Independensi (X1) berpengaruh positif dan signifikan terhadap kualitas audit pada PT Foximas Mandiri yaitu sebesar 68,3\%. Hal ini dipengaruhi oleh dimensi Independensi dalam pemrograman yaitu pada indikator bebas dari tekanan atau intervensi manajerial serta dimensi independensi dalam pelaporan yaitu pada indikator menghindari penggunaan kata yang tidak jelas dengan skor sebesar 118 dari 869 atau 13,58\% degan Gap sebesar 9,23\%, itu berarti auditor internal pada PT Foximas Mandiri terbebas dari tekanan atau intervensi manajerial dalam menentukan, mengeliminasi atau memodifikasi bagian-bagian tertentu dalam audit serta dalam menyajikan laporan auditor menghindari penggunaan kata-kata yang tidak jelas baik yang disengaja maupun tidak disengaja. Namun pada PT Foximas Mandiri masih terdapat kekurangan pada dimensi Independensi dalam Investigasi yaitu pada indikator akses langsung dan bebas atas sumber informasi dengan skor sebesar 93 dari 869 atau 10,70\% dengan Gap sebesar 28,47\%, itu berarti auditor internal belum memiliki kebebasan dalam mengakses secara langsung sumber informasi mengenai kegiatan perusahaan. Hasil penelitian ini sejalan dengan penelitian yang dilakukan oleh Ariany (2017) dan Trihapsari (2016) yang menjelaskan bahwa Independensi berpengaruh signifikan terhadap Kualitas Audit.

\section{Pengaruh Profesionalisme Terhadap Kualitas Audit}

Berdasarkan hasil penelitian, diperoleh hasil bahwa variabel Profesionalisme auditor internal (X2) berpengaruh positif dan signifikan terhadap kualitas audit pada PT Foximas Mandiri Bandung yaitu sebesar 67\%. Hal ini dipengaruhi oleh Dimensi Keyakinan terhadap Peraturan profesi dengan Indikator yakin pada 


\section{JURNAL AKUNTANSI, Vol. 10, No. 1, April (2021)}

aturan profesi dan standar profesi yang ada dengan skor sebesar 128 dari 1.485 atau sebesar 8,61\& dengan Gap sebesar 1,54\%, yang berarti auditor internal pada PT Foximas Mandiri selama ini meyakini bahwa yang berwenang untuk menilai pekerjaannya adalah rekan sesama profesi bukan pihak luar yang tidak memiliki kompetensi dalam bidang ilmu dan pekerjaan mereka. Namun pada PT Foximas Mandiri masih terdapat kekurangan pada dimensi Pengabdian pada profesi yaitu pada indikator Tingkat kepuasan batin berprofesi dengan skor sebesar 108 dari 1.485 atau 7,27\% dengan Gap sebesar 16,93\%, itu berarti selama ini dari hasil pekerjaan yang sudah diselesaikan, kompensasi yang Auditor harapkan belum memuaskan batin/ rohani. Hasil penelitian ini sejalan dengan hasil penelitian yang dilakukan oleh Nugrahini (2015) dan Ilhamsyah (2018) yang menjelaskan bahwa profesionalisme auditor intenal berpengaruh positif dan signifikan terhadap kualitas audit.

\section{PENUTUP \\ Simpulan}

Terdapat pengaruh positif dan signifikan Independensi Auditor Internal terhadap Kualitas Audit pada PT Foximas Mandiri. Hal ini dipengaruhi oleh dimensi Independensi dalam pemrograman yaitu pada Indikator bebas dari tekanan atau intevensi manajerial dan Independensi dalam pelaporan yaitu pada indikator menghindari penggunaan bahasa yang tidak jelas. Pada PT Foximas Mandiri masih terdapat kekurangan pada dimensi Independensi dalam Investigasi yaitu pada indikator akses langsung dan bebas atas sumber informasi. Terdapat pengaruh positif dan signifikan Profesionalisme Auditor Intenal terhadap Kualitas Audit pada PT Foximas Mandiri. Hal ini dipengaruhi oleh dimensi keyakinan terhadap peraturan profesi yaitu pada indikator yakin pada aturan dan standar profesi yang ada. Namun pada PT Foximas Mandiri masih terdapat keterbatasan atau kekurangan pada dimensi Pengabdian pada profesi yaitu pada indikator tingkat kepuasan batin berprofesi.

\section{Saran}

Berdasarkan analisis data dan hasil yang diperoleh dalam penelitian ini , terdapat beberapa saran yang dapat dipertimbangkan antara lain: a) Perlunya peningkatan kualitas audit dengan meningkatkan independensi auditor internal. Hal ini bisa dilakukan dengan cara manajerial memberikan dukunngan dan kebebasan bagi auditor internal untuk dapat mengakses secara langsung segala informasi mengenai kegiatan perusahaan. b) Peningkatan kualitas audit dengan meningkatkan Profesionalisme auditor internal. Hal ini bisa dilakukan dengan meningkatkan kompensasi dari hasil pekerjaan yang sudah diselsaikan, sehingga kompensasi yang Auditor harapkan memenuhi kepuasan batin/ rohani. c) Keterbatasan penelitian ini terletak pada jumlah sampel penelitian yang diambil. Sehingga akan lebih baik untuk penelitian selanjutnya dapat menambahkan jumlah sampel pada perusahaan lainnya serta menambahkan dimensi yang lainnya yang dapat meningkatkan kualitas audit

\section{REFERENSI}

Ardianingsih. Arum. 2018. Audit Laporan Keuangan. Jakarta: Sinar Grafika Offset.

Ariany. Vince. 2017. "Pengaruh Independensi dan Kompetensi Auditor Terhadap Kualitas Audit Internal Pada Bank BUMN di Medan”. Owner Riset \& Jurnal Akuntansi. 1(1), 62 - 68. ISSN: 2548 - 9224.

Fatihudin. Didin. 2015. Metode Penelitian untuk Ilmu Ekonomi, Manajemen, dan Akuntansi. Sidoarjo: Zifatama publisher.

Hery. 2016. Auditing Pemeriksaan Akuntansi Berbasis Standar Audit Internasional dan Asurans. Jakarta: PT. Grasindo.

Ilhamsyah. Fadil. 2018. "Pengaruh Kompetensi, Profesionalisme dan Pengalaman Kerja Auditor Terhadap Kualitas Audit Internal Pada Perbankan”. Jurnal Akuntansi. 6 (3), 1-19.

Junaidi. Dan Nurdiono. 2016. Kualitas Audit Perspektif Opini Going Concern. Yogyakarta: Andi.

Menteri Keuangan Sri Mulyani. 2018. Auditor Internal Perlu Menjaga Profesionalisme. Tersedia : https://www.kemenkeu.go.id/publikasi/berita/auditor-internal-perlu- menjaga-profesionalisme/ diakses tanggal 15 Maret 2020 
Nasution. D.A.D., Ramadhan. R.P. dan Barus. D.M. 2019. Audit Sektor Publik. Sidoarjo: Uwais Inspirasi Indonesia.

Nugrahini. Putri. 2015. Pengaruh Kompetensi dan Profesionalisme Auditor Internal Terhadap Kualitas Audit (Studi Empiris Pada BUMN dan BUMD di Kota Yogyakarta. Skripsi S1 Fakultas Ekonomi UNY: http://eprints.uny.ac.id/eprint/15261

Ramdani, Y. 2017. Kualitas Audit Dalam Kasus PT. KAI. Kompasiana. 3 Maret 2017 Tersedia: https://www.kompasiana.com/meu/58b8ad9d6c7a617c1557d321/kualitas- audit-dalam-kasus-ptkai, diakses tanggal 12 Maret 2020

Riyanto. Slamet. Dan Harmawan. Aglis. A. 2020. Metode Riset Penelitian Kuantitatif Penelitian di Bidang Manajemen, Teknik Pendidikan dan Eksperimen. Sleman: Deepublish.

Rukajat. Ajat. 2018. Pendekatan Penelitian Kuantitatif. Sleman: Deepublish.

Rusman. 2017. Belajar dan Pembelajaran Berorientasi Standar Pendidikan. Jakarta: Kencana.

Sugiyono. 2017. Metode Penelitian Kuantitatif,Kualitatif dan R\&D. Bandung: Alfabeta.

Sujarweni. W.V. 2015. Metodologi Penelitian Bisnis \& Ekonomi. Yogyakarta: Pustaka Baru Press.

Syabani. Yusuf. A.M. 2018. Profesi Keguruan Menjadi Guru Yang Religius dan Bermartabat. Gresik: Caremedia Comunication.

Trihapsari. A.D. 2016. "Pengaruh Etika, Independensi, Pengalaman Audit dan Premature Sign Off Terhadap Kualitas Audit”. Accounting Analysis Journal. 5 (1), 1-7. ISSN: 2252 - 6765.

Widi. R.K. 2018. Menggelorakan Penelitian, Pengenalan dan Penuntun Pelaksanaan Penelitian. Yogyakarta: Deepublish Publisher.

Yadiati. Wiwin. dan Abdulloh. Mubarok. 2017. Kualitas Pelaporan Keuangan. Jakarta: Kencana.

Zamzami. F., Faiz. I.A. dan Mukhlis. 2015. Audit Internal, Konsep dan Praktik. Yogyakarta: Gadjah Mada University Press. 